\title{
DETERMINAN CITRA MEREK PADA IKLAN PRODUK GAWAI "VIVO” BERDASARKAN ASPEK “CELEBRITY ENDORSER”
}

\author{
Fabianus Fensi ${ }^{1)}$ dan Michael Christian ${ }^{2)}$ \\ 1) IImu Komunikasi, Universitas Bunda Mulia \\ ${ }^{2)}$ Manajemen, Universitas Bunda Mulia \\ Disetujui 23 Agustus 2018
}

\begin{abstract}
The impact of using influencers in a product such as a smartphone that can create stronger advertising effectiveness. This strengthens the understanding of advertising in an effort to tell stories, arouse emotions, create fantasy, and impact to provide strong visuals. This study aims to analyze the effect of VIVO brand image. By using quantitative research and processed with SPSS 25.0, the results of this study explain that brand image is partially influenced by factors such as endorser self quality, similarity, and persuasive power displayed. While factors can be trusted, expertise, physical attractiveness, popularity does not affect. Simultaneously the brand image in the VIVO device is influenced by Trustworthy factors, Expertise, Physical Attraction, Quality Appreciated, Similarity, Popularity, and Persuasive Strength.
\end{abstract}

Keywords: brand image, device, endorser, influencer

\begin{abstract}
ABSTRAK
Dampak dari penggunaan influencer dalam dalam suatu produk seperti gawai yang dapat menciptakan efektivitas iklan yang lebih kuat. Hal ini menguatkan pemahaman iklan dalam upaya untuk menceritakan kisah, membangkitkan emosi, menciptakan fantasi, dan dampak memberikan visual yang kuat. Penelitian ini bertujuan untuk menganalisis pengaruh citra merek gawai VIVO. Dengan menggunakan penelitian kuantitatif dan diolah dengan SPSS 25.0 hasil penelitian ini menjelaskan citra merek secara parsial dipengaruhi oleh faktor-faktor seperti kualitas diri endorser, kesamaan, dan kekuatan persuasif yang ditampilkan. Sedangkan faktor-faktor dapat dipercaya, keahlian, daya tarik fisik, popularitas tidak berpengaruhi. Secara simultan citra merek pada gawai VIVO dipengaruhi oleh faktorfaktor Dapat Dipercaya, Keahlian, Daya Tarik Fisik, Kualitas Dihargai, Kesamaan, Popularitas, dan Kekuatan Persuasif.

Kata kunci: citra merek, gawai, endorser, influencer
\end{abstract}

\section{PENDAHULUAN}

\section{Latar Belakang}

Pemakaian dan kebutuhan gawai atau gadget/smartphone di Indonesia masih tingi. Hal ini dapat dilihat dari pangsa pasar gawai di Indonesia dalam tiga tahun terakhir. Hasil studi riset yang dilakukan

\footnotetext{
*Korespondensi Penulis:

E-mail: michaelchristianid@gmail.com
}

oleh Statista (www.statista.com, 2018) mengungkapkan bahwa pangsa pasar gawai di Indonesia masih dikuasai oleh Samsung yang pada tahun 2017 mencapai angka $30 \%$. Hal yang menarik dari hasil tersebut adalah meningkatnya gairah pasar terhadap gawai-gawai yang dengan basis pabrikan Cina, seperti OPPO dan Vivo.

$$
\text { Data pada tabel di bawah }
$$
menjelaskan bahwa kepopuleran suatu merek gawai dapat menjadi salah satu 
faktor penentu penjualan gawai yang akan membentuk besaran pangsa pasar. Popularitas suatu merek gawai mengartikan sejauh mana merek tersebut setidaknya dapat diingat pengguna gawai, atau secara konsep komunikasi pemasaran disebut dengan Top of Mind.

Tabel 1. Pangsa Pasar Gawai di Indonesia Periode 2014-2017

\begin{tabular}{llllll}
\multirow{2}{*}{ Merek Gawai } & $\mathbf{0 4 2 0 1 4}$ & $\mathbf{Q 4 2 0 1 5}$ & $\mathbf{Q 2 2 0 1 6}$ & $\mathbf{Q 3 ~ 2 0 1 6}$ & $\mathbf{Q 3 ~ 2 0 1 7}$ \\
Samsung & 21,96 & 19,76 & 26 & 32,2 & 30 \\
\hline Oppo & - & - & 19 & 16,7 & 25,5 \\
\hline Advan & 8,7 & 8,8 & 8 & 6 & 8,3 \\
\hline Vivo & - & - & - & - & 7,5 \\
\hline Xiaomi & - & - & - & - & $6,2 \%$ \\
\hline Asus & 11 & 21,96 & 9 & 8,2 & - \\
\hline Smartfren & 11,1 & 9,7 & - & 5,7 & - \\
\hline Lenovo & 2,5 & 9,2 & 6 & 5,7 & - \\
\hline Lainnya & 44,7 & 30,7 & 32 & 25,5 & 22,5 \\
\hline Sumar & & & & &
\end{tabular}

Sumber : www.statista.com, 2018

Beberapa riset mengenai popularitas merek gawai di Indonesia menjelaskan bahwa gawai pabrikan asal Cina berhasil menunjukkan eksistensinya di bagi pengguna lokal di Indonesia. Frontier Consulting Group mengungkapkan bahwa pada tahun 2017 Top Brand Index (TBI) menunjukkan angka yang beragam (www.topbrand-award.com, 2018.), yaitu Samsung (46,4\%), Nokia $(8,8 \%)$, Blackberry (8\%), iPhone (5,1\%), Smartfren $(5,1 \%)$, Lenovo $(4,4 \%)$, Oppo $(4,1 \%)$ dan Asus $(3,8 \%)$. Sedangkan MarkPlus Inc (www.marketeers.com,

2017) mengungkapkan bahwa WOW Brand atau merek-merek yang dianggap populer pada kategori Communication, High-Tech \& Media tahun 2017 yaitu Samsung $(0,85)$, Xiaomi $(0,72)$, dan Oppo $(0,65)$. Hasil yang hampir sama dilakukan oleh lembaga riset Indonesia's Largest Carrier-Neutral Data Center (IDC) menunjukkan gawai TOP di Indonesia pada tahun 2017, yaitu Samsung (30\%), Oppo (25,5\%), Xiaomi $(22,5 \%)$, Advan (8,3\%), Lainnya (6,2\%).

Data-data dari beberapa lembaga riset dapat menjelaskan beberapa kesamaan dan fenomena. Pertama, merek Samsung merupakan gawai yang memiliki konsistensi menjadi merek gawai favorit bagi pengguna gawai di Indonesia. Kedua, fenomena gawai yang berasal dari Cina terus menunjukkan eksistensinya di Indonesia. Strategi komunikasi pemasaran yang dilakukan oleh perusahaan-perusahaan gawai asal Cina sepertinya membuahkan hasil. Strategi komunikasi pemasaran yang cenderung agresif menjadi pemicu efektif dalam menciptakan citra merek yang populer bagi masyarakat. Strategi komunikasi pemasaran 360 derajat dengan pemanfaatan kanal digital dan media sosial pada kegiatan above the line dan below the line dipakai oleh gawai dengan merek ZTE (Supriyadi, 2014). Merek gawai Oppo dan Vivo yang merupakan satu perusahaan di Cina mengandalkan strategi influencer seperti Agnes Mo, Afgan, Pevita Pierce, Prilly Latuconsina, Al Ghazali, Shireen dan Zaskia Sungkar (Suryadi, 2017; Bachdar, 2017).

Dampak dari penggunaan influencer dalam dalam suatu produk seperti gawai yang dapat menciptakan efektivitas iklan yang lebih kuat, apalagi ditampilkan di media-media masal seperti televisi. Hal ini menguatkan pemahaman iklan dalam upaya untuk menceritakan 
kisah, membangkitkan emosi, menciptakan fantasi, dan dampak memberikan visual yang kuat (Moriarty, Mitchell, \& Wells, 2011). Influencer atau yang dikenal dengan celebrity endorser memiliki peranan penting dalam keberhasilan penjualan suatu produk. Salah satu cara agar audience tertarik untuk memperhatikan dan menerima pesan dari sebuah iklan yaitu dengan menggunakan sosok selebriti sebagai bintang iklan yang disebut juga sebagai celebrity endorser. Celebrity endorser merupakan tokoh (aktor, penghibur, atau atlet) yang dikenal masyarakat karena prestasinya dalam bidang berbeda dari golongan produk yang didukung dan diharapkan akan mempengaruhi sikap perilaku konsumen yang baik pada produk yang didukung (Shimp, 2003).

Shimp (2007:304) menjelaskan dimensi-dimensi yang terdapat pada faktor celebrity endorser yaitu Trustworthiness, Expertise, Attractiveness, Respect, dan Similarity. Turstworthiness (kepercayaan) mengacu pada kejujuran, integritas dan dapat dipercayainya pemberi pesan, Expertise (keahlian) mengacu pada pengetahuan, pengalaman serta keterampilan pemberi pesan yang memiliki keterkaitan dengan merek yang didukungnya. Physical Attractiveness (daya tarik fisik) merupakan daya tarik selebriti yang bukan hanya fisik tetapi juga kecerdasan, sifat, kepribadian, gaya hidup dan sebagainya. Respect (respek) merupakan dihargainya seorang selebriti karena prestasi atau kepandaian yang dimiliki. Similarity (kesamaan) mengacu pada tingkat kesamaan selebriti dengan audience seperti usia, jenis kelamin, budaya, dan sebagainya.

Celebrity endorser dalam jangka panjangnya akan berfungsi sebagai pendorong untuk menguatkan citra merek supaya tetap diingat oleh penggunanya. Menurut (Kotler \& Keller, 2012), citra merek merupakan persepsi mengenai suatu merek berupa asosiasi-asosiasi yang menempel pada merek tersebut. Shimp (2007) menjelaskan bahwa citra merek adalah suatu kumpulan asosiasi merek yang didasari oleh berbagai ketertarikan yang dikembangkan oleh konsumen pada setiap waktu, brand seperti manusia dapat berupa gagasan yang mempunyai masing-masing personality. Terciptanya citra merek yang tepat untuk suatu produk, maka akan sangat berguna bagi pemasar karena citra merek akan mempengaruhi penilaian konsumen atas alternative brand yang diharapkan. Semakin baik citra merek yang melekat pada produk, maka konsumen akan semakin tertarik untuk membeli produk tersebut.

Agnes Monica atau Agnes Mo merupakan seorang figur selebriti yang memiliki nama besar di Indonesia dan perlahan mulai merambah kancah Internasional sebagai penyanyi. Nama besar ini dimanfaatkan oleh Vivo sebagai pemain baru gawai di Indonesia untuk membentuk kesadaran merek dan sekaligus popularitas merek Vivo di Indonesia. Status selebriti dengan skala internasional dengan nama besar menjadi menarik untuk diteliti dalam penelitian ini khususnya dalam produk gawai Vivo yang merupakan gawai asal pabrikan Cina. Hal selanjutnya yang menjadi pertimbangan adalah dinamika persaingan pada kategori gawai di Indonesia yang sangat cepat. Beberapa waktu popularitas merek-merek gawai besar perlahan pudar bahkan ada yang menghilang, misalnya Nokia, Blackberry, dan HTC.

Dari sisi riset pendahulu, di Indonesia beberapa penelitian mengenai celebrity endorser pada berbagai merek produk/jasa menjelaskan hasil yang beragam. Rini \& Astuti, (2012) menjelaskan bahwa ada pengaruh positif dan signifikan variabel visibilitas, kredibilitas, daya tarik dan kekuatan terhadap pembentukan citra merek Honda Vario yang dibintangi oleh Agnes Monica. Dalam kaitannya dengan keinginan untuk membeli suatu produk sebagai dampak dari keberhasilan pengaruh Al Ghazali sebagai Celebritty Endorser dijelaskan oleh Ismayanti \& Santika (2017). (Rodiyaan \& Madiawati, 2016) mengungkapkan bahwa celebrity endorser "Agnes Monica" 
memiliki pengaruh secara simultan pada citra merek Sampo Clear wanita. Marselina \& Siregar (2017) memberikan hasil bahwa secara parsial faktor trustworthiness, attractiveness dan similarity berpengaruh terhadap citra merek namun faktor expertise dan respect tidak berpengaruh. Hasil penelitian Saparso \& Lestari (2009) mengungkapkan bahwa Tamara Blezinsky, Luna Maya, dan Dian Sastro memberikan pengaruh terhadap citra merek sabun Lux khususnya pada faktor product match, popularity, credibility, target audience, pyshical attractiveness, dan interest of endorser. Beberapa faktor seperti celebrity controversy risk, multiple endorsement, dan celebrity brand user justru tidak memberikan pengaruh pada citra merek sabun Lux.

\section{Masalah Penelitian}

Adapun masalah dalam penelitian ini adalah sebagai berikut:

1. Apakah Citra merek secara parsial dipengaruhi oleh faktor dapat dipercaya oleh sosok selebriti

2. Apakah Citra merek secara parsial dipengaruhi oleh faktor keahlian sosok selebriti beriklan

3. Apakah Citra merek secara parsial dipengaruhi oleh faktor daya tarik fisik sosok selebriti

4. Apakah Citra merek secara parsial dipengaruhi oleh faktor kualitas sosok selebriti yang dihargai

5. Apakah Citra merek secara parsial dipengaruhi oleh faktor kesamaan karakter produk dengan sosok selebriti

6. Apakah Citra merek secara parsial dipengaruhi oleh faktor popularitas sosok selebriti

7. Apakah Citra merek secara parsial dipengaruhi oleh faktor kekuatan persuasif dari sosok selebriti

8. Apakah Citra merek secara simultan dipengaruhi oleh faktor-faktor dapat dipercaya, keahlian, daya tarik fisik, kualitas, kesamaan karakter, popularitas, dan kekuatan persuasif sosok selebriti

\section{Tujuan Penelitian}

Tujuan penelitian ini adalah sebagai berikut:

1. Untuk menganalisis apakah Citra merek secara parsial dipengaruhi oleh faktor dapat dipercaya oleh sosok selebriti

2. Untuk menganalisis apakah Citra merek secara parsial dipengaruhi oleh faktor keahlian sosok selebriti beriklan

3. Untuk menganalisis apakah Citra merek secara parsial dipengaruhi oleh faktor daya tarik fisik sosok selebriti

4. Untuk menganalisis apakah Citra merek secara parsial dipengaruhi oleh faktor kualitas sosok selebriti yang dihargai

5. Untuk menganalisis apakah Citra merek secara parsial dipengaruhi oleh faktor kesamaan karakter produk dengan sosok selebriti

6. Untuk menganalisis apakah Citra merek secara parsial dipengaruhi oleh faktor popularitas sosok selebriti

7. Untuk menganalisis apakah Citra merek secara parsial dipengaruhi oleh faktor kekuatan persuasif dari sosok selebriti

8. Untuk menganalisis apakah Citra merek secara simultan dipengaruhi oleh faktor-faktor dapat dipercaya, keahlian, daya tarik fisik, kualitas, kesamaan karakter, popularitas, dan kekuatan persuasif sosok selebriti

\section{TINJAUAN PUSTAKA}

\section{Keterkaitan Peubah Bebas dengan Peubah Terikat}

Shimp (2007:38) menjelaskan bahwa brand image yaitu suatu kumpulan asosiasi merek yang didasari oleh berbagai ketertarikan yang dikembangkan oleh konsumen pada setiap waktu, brand seperti manusia dapat berupa gagasan yang mempunyai masing-masing personality. Schiffman dan Kanuk (2000:141) dalam Selfi Stefani (2015) menuturkan bahwa konsumen senantiasa memilih merek berdasarkan citranya. Jika konsumen tidak mempunyai pengalaman dengan suatu produk, maka mereka cenderung untuk mempercayai merek yang disukai atau 
terkenal. Citra merek positif berkaitan dengan kesetiaan konsumen, kepercayaan konsumen mengenai nilai merek yang positif, dan kesediaan untuk mencari merek tersebut. Citra merek yang positif juga membantu meningkatkan minat konsumen dalam menghadapi berbagai kegiatan pemasaran pesaing. Simamora (2004:65) menyebutkan terdapat 3 bagian yang termasuk dalam komponen brand image, yaitu: 1) Citra perusahaan (corporate image), adalah sekumpulan asosiasi yang dipersepsikan konsumen terhadap perusahaan yang membuat suatu produk atau jasa. 2) Citra pemakai (user image), adalah sekumpulan asosiasi yang dipersepsikan konsumen terhadap pemakai yang menggunakan suatu barang atau jasa. 3) Citra produk (product image), adalah sekumpulan asosiasi yang dipersepsikan konsumen terhadap suatu produk.

Rossiter \& Smidts (2012
menjelaskan proses mengevaluasi endorser yang potensial berdasarkan persepsi masyarakat terhadap endorser. Visibilily memiliki dirnensi seberapa jauh popularitas seorang selebriti yang mewakili produk tersebut, apabila dihubungkan dalam popularitas, maka dapat ditentukan dengan seberapa banyak yang dimiliki oleh seorang Celebrity Endorser (Popularity) dan bagaimana tingkat keseringan tampilnya didepan khalayak (Appearances). Kredibilitas (credibility) seorang selebriti lebih banyak berhubungan dengan dua hal, yaitu keahlian dan objektivitas. Keahlian berkaitan dengan pengetahuan selebritis tentang produk yang diiklankan. Sedangkan objektivitas merujuk pada kemampuan selebriti untuk memberikan keyakinan atau percaya diri pada masyarakat tentang suatu produk. Selebriti yang memiliki kemampuan yang sudah dipercaya kredibilitasnya akan mewakili merek yang diiklankan.

Attraction berkaitan dengan endorser yang memiliki daya tarik khususnya yang bertujuan untuk memengaruhi penerimaan pesan. Faktor attraction dari endorser dapat dilihat dari berbagai aspek seperti Daya Tarik secara
Fisik di mana menjelaskan bahwa persepsi masyarakat mempertimbangkan penampilan fisik endorser yang dianggap menarik. Faktor selanjutnya adalah Daya Tarik berdasarkan Kepribadian endorser. Hal ini menjelaskan bahwa masyarakat akan berpersepsi penampilan non-fisik seperti kepribadian endorser dapat menjadi daya tarik tersendiri. Pada umumnya masyarakat menyukai endorser yang terbuka, penuh candaan, dan alami. Faktor berikutnya adalah similarity di mana persepsi masyarakat ditentukan oleh kesamaan yang dimiliki endorser, baik dari faktor usia, hobi, aktivitas yang dijalani maupun masalah yang dihadapi. Faktor terakhir yaitu power yang menjelaskan kekuatan yang dimiliki endorser untuk "memerintahkan" masyarakat yang menjadi target untuk membeli. Power juga berkaitan dengan kemampuan dalam persuasi terhadap produk yang sedang diiklankan.

\section{Hipotesis}

Hipotesis yang digunakan dalam penelitian ini yaitu:

H1: Citra merek secara parsial dipengaruhi oleh faktor dapat dipercaya oleh sosok selebriti

H2: Citra merek secara parsial dipengaruhi oleh faktor keahlian sosok selebriti beriklan H3: Citra merek secara parsial dipengaruhi oleh faktor daya tarik fisik sosok selebriti

H4: Citra merek secara parsial dipengaruhi oleh faktor kualitas sosok selebriti yang dihargai

H5: Citra merek secara parsial dipengaruhi oleh faktor kesamaan karakter produk dengan sosok selebriti

H6: Citra merek secara parsial dipengaruhi oleh faktor popularitas sosok selebriti

H7: Citra merek secara parsial dipengaruhi oleh faktor kekuatan persuasif dari sosok selebriti

H8: Citra merek secara simultan dipengaruhi oleh faktor-faktor dapat dipercaya, keahlian, daya tarik fisik, kualitas, kesamaan karakter, popularitas, dan kekuatan persuasif sosok selebriti 


\section{METODE PENELITIAN}

\section{Pengembangan Instrumen}

Penelitian ini menggunakan faktorfaktor pada celebrity endorser yang digunakan oleh Shimp (2003) dan Rossiter \& Smidts (2012) yang terdiri atas indikatorindikator dapat dipercaya, keahlian, daya tarik fisik, kualitas sosok selebriti yang dihargai, kesamaan karakter produk dengan sosok selebriti, popularitas sosok selebriti, kekuatan persuasif dari sosok selebriti. Faktor merek terdiri atas citra perusahaan, citra penggunaan (fungsional), dan citra produk Shimp (2007). Skala ukur yang digunakan dalam penelitian ini adalah ordinal dengan rentang skala likert 1-5 dengan angka 3 disimbolkan dengan netral.

\section{Teknik Analisis Data}

Penelitian ini menggunakan
penelitian kuantitatif, di mana menggunakan teori secara deduktif yang bertujuan untuk menguji atau melakukan verifikasi suatu teori (Creswell, 2014). Dalam menjelaskan relasi antara asumsiasumsi dan prosedur-prosedur untuk melakukan penerapan asumsi-asumsi yang ada, penelitian ini menggunakan metode survei. Karakter sampel dalam penelitian ini adalah pengguna gawai yang mengenal sosok selebriti Agnes Monica dan yang mengetahui gawai dengan merek Vivo. Jumlah sampel yang digunakan dalam penelitian ini sebanyak 136 orang. Jumlah ini sudah memenuhi syarat minimal jumlah sampel dengan menggunakan Hair et. al. (minimal jumlah indikator dikali 5 sampai dengan10). Pengukuran penelitian ini menggunakan analisis regresi berganda yang akan diolah dengan aplikasi Statistical Package for Social Science (SPSS).
Penelitian ini menggunakan angka selang kepercayaan sebesar 95\% dan angka galat sebesar 5\%. Selain beberapa uji analisis seperti kesahihan, kehandalan, kesesuaian model/konstruk, uji hipotesis baik secara parsial mau pun simultan, hasil yang juga akan dijelaskan adalah statisitik deskriptif responden.

\section{HASIL DAN PEMBAHASAN}

\section{Profil Responden}

Berdasarkan data di bawah, dapat terlihat bahwa responden merata berdasarkan gender. Responden laki-laki yang dilibatkan dalam penelitian ini sebanyak 87 orang $(64 \%)$ dan responden perempuan sebanyak 49 orang (36\%). Data ini menjelaskan juga bahwa responden lakilaki dalam penelitian ini lebih dominan dilibatkan. Berdasarkan data usia responden dapat terlihat bahwa responden yang berusia $<20$ tahun sebanyak 74 orang, usia 20-30 tahun sebanyak 55 orang, usia 31-40 sebanyak 6 orang dan usia $>40$ tahun sebanyak 1 orang. Responden dengan usia muda (millennial) lebih dominan dilibatkan yaitu lebih dari $50 \%$. Berdasarkan jumlah smartphone yang digunakan dalam penelitian ini dapat terlihat bahwa responden yang memiliki 2 unit smartphone sebanyak 83 orang $(61 \%)$, responden yang memiliki hanya 1 unit smartphone dalam sehari-hari sebanyak 47 orang $(34,6 \%)$, dan responden yang memiliki 3 unit smartphone sebanyak 6 orang $(4,4 \%)$. Dari data ini dapat dijelaskan juga bahwa responden yang berasal dari kelompok millineal memiliki lebih dari 1 unit smartphone untuk kepentingannya sehari-hari. 


\section{Tabel 2. Deskripsi Profil Responden}

\begin{tabular}{llrr}
\hline Deskripsi & Keterangan & Jumlah & \multicolumn{1}{l}{$\%$} \\
\hline \multirow{2}{*}{ Gender } & Laki-laki & 87 & $64,0 \%$ \\
\cline { 2 - 4 } & Perempuan & 49 & $36,0 \%$ \\
\hline \multirow{3}{*}{ Usia } & $<20$ tahun & 74 & $54,4 \%$ \\
\cline { 2 - 4 } & $20-30$ tahun & 55 & $40,4 \%$ \\
\cline { 2 - 4 } & $31-40$ tahun & 6 & $4,4 \%$ \\
\cline { 2 - 4 } Status pekerjaan anda saat ini & Karyawan swasta & \multicolumn{1}{c}{54} & $0,7 \%$ \\
\cline { 2 - 4 } & PNS & $89,7 \%$ \\
\cline { 2 - 4 } & Tidak Bekerja & 74 & $54,4 \%$ \\
\hline \multirow{3}{*}{$\begin{array}{l}\text { Jumlah Unit Smartphone yang } \\
\text { Digunakan }\end{array}$} & 1 unit smartphone & 47 & 34,6 \\
\cline { 2 - 4 } & 2 unit smartphone & 83 & 61,0 \\
\cline { 2 - 4 } & 3 unit smartphone & 6 & 4,4 \\
\hline
\end{tabular}

Sumber: SPSS 25.0; $\mathrm{n}=136$

\section{Uji Kesahian dan Kehandalan}

Pada tabel berikut ditampilkan hasil uji kehandalan dan kesahian pada penelitian ini.

Tabel 3. Uji Kesahian Keseluruhan Item $(\mathbf{r}$ tabel = 0,174)

\begin{tabular}{l|l|l|l|l|l} 
Item & $\begin{array}{c}\text { Corrected Item- } \\
\text { Total Correlation }\end{array}$ & $\begin{array}{c}\text { Keteranga } \\
\mathrm{n}\end{array}$ & \multicolumn{1}{|c|}{$\begin{array}{c}\text { Item } \\
\text { Total } \\
\text { Correlation }\end{array}$} & $\begin{array}{c}\text { Keteranga } \\
\mathrm{n}\end{array}$ \\
\hline P1 & .274 & Sahih & P14 & .421 & Sahih \\
\hline P2 & .576 & Sahih & P15 & .525 & Sahih \\
\hline P3 & .397 & Sahih & P16 & .483 & Sahih \\
\hline P4 & .618 & Sahih & P17 & .555 & Sahih \\
\hline P5 & .578 & Sahih & P18 & .549 & Sahih \\
\hline P6 & .606 & Sahih & P19 & .516 & Sahih \\
\hline P7 & .633 & Sahih & P20 & .572 & Sahih \\
\hline P8 & .572 & Sahih & P21 & .633 & Sahih \\
\hline P9 & .657 & Sahih & P22 & .572 & Sahih \\
\hline P10 & .528 & Sahih & P23 & .657 & Sahih \\
\hline P11 & .427 & Sahih & P24 & .528 & Sahih \\
\hline P12 & .526 & Sahih & P25 & .427 & Sahih \\
\hline P13 & .547 & Sahih & & &
\end{tabular}

Sumber: SPSS 25.0; $\mathrm{n}=136$

Pada tabel di atas, dapat dilihat bahwa item kuesioner yang digunakan baik secara keseluruhan item dan per kelompok dapat dinyatakan sahih. Angka pada corrected item correlation berada di atas angka tabel $\mathrm{r}$ untuk jumlah $\mathrm{n}$ sebanyak 136 yaitu 0,174 sehingga dapat dinyatakan sahih. 


\section{Tabel 4. Uji Kehandalan Keseluruhan Item}

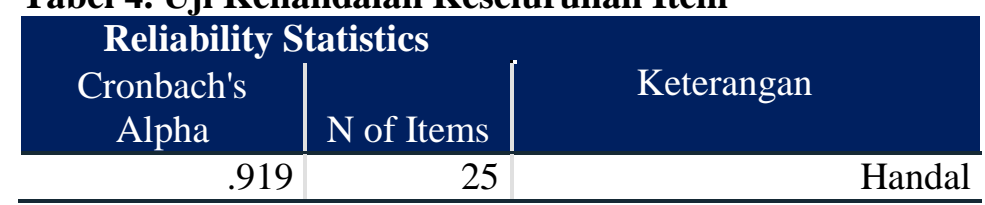

Sumber: SPSS $25.0 ; n=136$

Pada tabel di atas, dapat dilihat bahwa angka pada Cronbach's Alpha berada di atas angka 0,1684 atau dapat dijelaskan juga bahwa nilai Cronbach's Alpha berada di atas 0,7 sehingga dapat dinyatakan handal.

\section{Uji Normalitas}

Uji normalitas pada penelitian ini diuji dengan menggunakan metode Normal $P$-Plot dengan hasil uji ditampilkan pada gambar berikut:

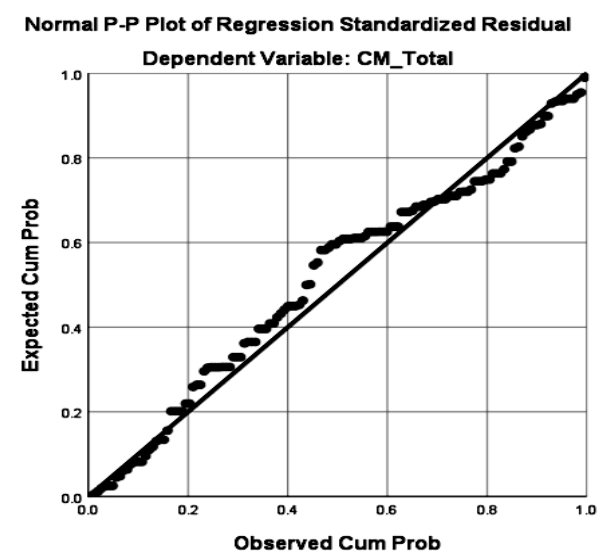

\section{Gambar 1. Uji Normalitas Dengan Normal P-P Plot Sumber: SPSS 25.0; $n=136$}

Berdasarkan gambar di atas dapat ditunjukkan bahwa sebaran titik-titik berada disekitar garis diagonal. Hal ini menjelaskan bahwa dalam penelitian ini data berdistribusi normal. Hal ini juga dapat menjelaskan bahwa data empirik yang didapat dari lapangan terdistribusi normal.

\section{Uji Multikolinieritas}

Uji multikolinieritas pada penelitian ini diuji dengan melihat pada angka Variance Inflation Factor (VIF) dan Tolerance (Tol) dengan hasil uji ditampilkan pada tabel berikut: 


\section{Tabel 5. Uji Multikolineritas}

\begin{tabular}{ll|l|l}
\hline \multirow{2}{*}{$\begin{array}{l}\text { Model } \\
1\end{array}$} & \multicolumn{2}{|c}{ Collinearity Statistics } \\
Tolerance & VIF \\
\cline { 2 - 4 } & (Constant) & & \\
\hline & Dapat_Dipercaya_Total & .646 & 1.548 \\
\hline Keahlian_Total & .347 & 2.884 \\
\hline Daya_Tarik_Fisik_Total & .322 & 3.104 \\
\hline Kualitas_Dihargai_Total & .585 & 1.710 \\
\hline Kesamaan_Total & .774 & 1.291 \\
\hline Popularitas_Total & .605 & 1.654 \\
\hline Kekuatan_Persuasif_Total & .575 & 1.740 \\
\hline
\end{tabular}

Sumber: SPSS 25.0; $\mathrm{n}=136$

Berdasarkan tabel di atas dapat dijelaskan bahwa angka yang diperoleh pada kolom Tol berada di atas 0,1 dan angka pada kolom VIF berada di bawah angka 10. Hal ini menyatakan bahwa tidak terjadi gejala multikolinieritas. Hasil ini menjelaskan bahwa peubah yang berkorelasi kuat dengan peubah lainnya dalam model penelitian ini, kekuatan prediksinya bersifat handal dan stabil atau dapat dijelaskan juga bahwa tidak terjadi korelasi antar peubah bebas.

\section{Uji Heteroskedastisitas}

Uji heteroskedastisitas pada penelitian ini ditampilkan pada gambar berikut

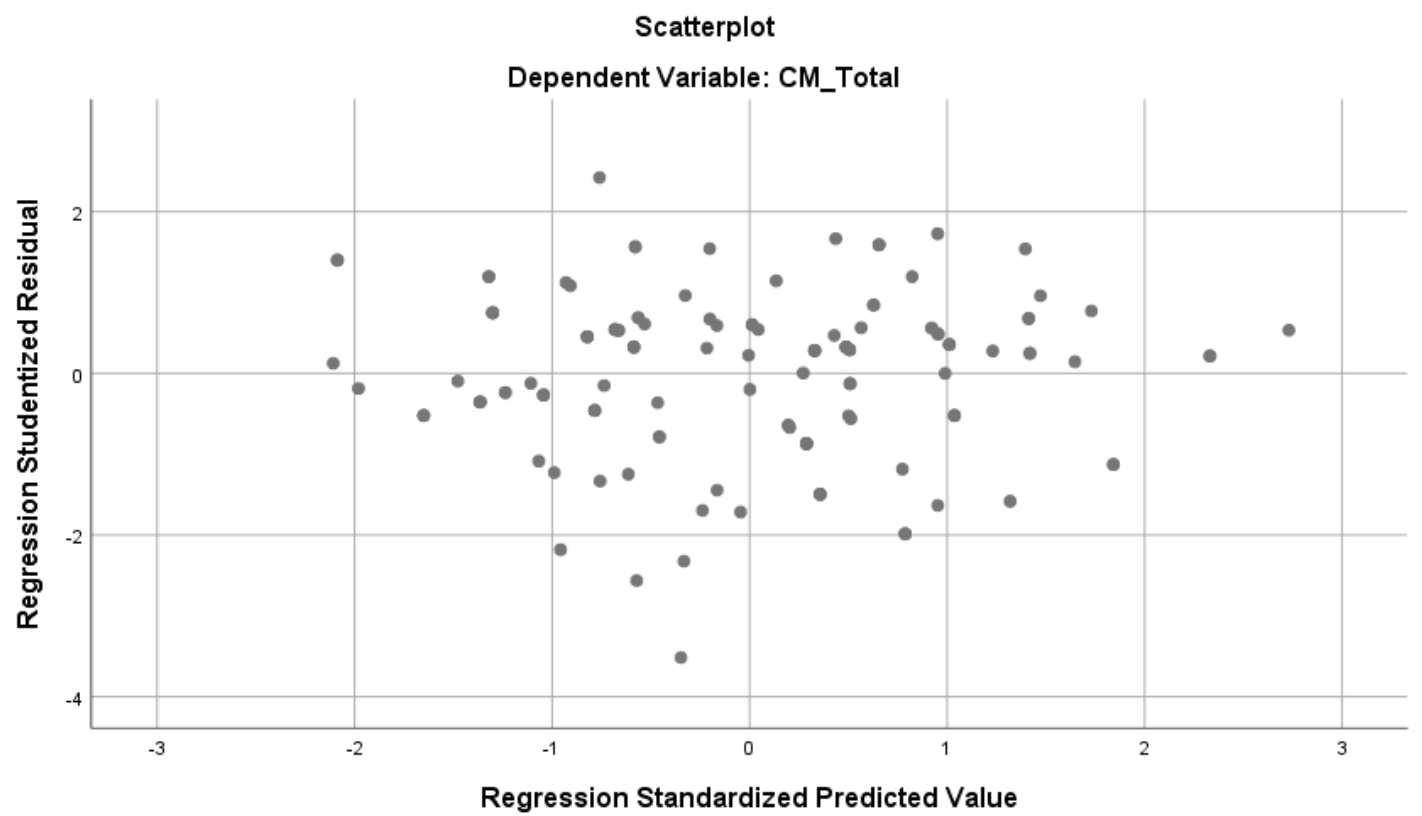

Gambar 2. Uji Heteroskedastisitas Dengan Scatterplot Sumber: SPSS 25.0; $n=136$ 
Berdasarkan tabel di atas dapat dijelaskan bahwa sebaran titik-titik pada scatterplot menyebar dan tidak membentuk pola di satu titik tertentu. Hal ini menyatakan bahwa tidak terjadi gejala heteroskedastisitas. Hasil ini menjelaskan bahwa tidak ada ketidaksamaan varian dari residual untuk keseluruhan pengamatan pada model regresi linear dalam penelitian ini.

\section{Kesesuaian Struktur Model}

Kesesuaian struktur model pada penelitian ini ditampilkan pada tabel berikut:

Tabel 6. Kesesuaian Struktur Model

\begin{tabular}{l|c|r|r|r} 
& & \multicolumn{3}{|c}{ Model Summary $^{\mathbf{b}}$} \\
Model & $\mathrm{R}$ & R Square & $\begin{array}{c}\text { Adjusted R } \\
\text { Square }\end{array}$ & Std. Error of the Estimate \\
\hline 1 & $.917^{\mathrm{a}}$ & .841 & .833 & 2.48995 \\
\hline
\end{tabular}

a. Predictors: (Constant), Kekuatan_Persuasif_Total, Kualitas_Diri_Total,

Kesamaan_Total, Dapat_Dipercaya_Total, Popularitas_Total, Keahlian_Total,

Daya_Tarik_Fisik_Total

b. Dependent Variable: CM_Total

Sumber: SPSS 25.0; $n=136$

Berdasarkan tabel di atas, dapat dijelaskan bahwa angka pada Adjusted $R$ Square menjelaskan bahwa Citra Merek dapat dijelaskan dengan perubahan sebesar $83,3 \%$ dan sisanya dipengaruhi oleh faktor lain yang tidak terdapat di dalam penelitian ini. Angka ini relatif besar sehingga faktorfaktor spesifik lain seperti misalnya peranan media beriklan dan tipe pada smartphone yang diiklankan sebesar $16,7 \%$ juga dirasa perlu diteliti untuk penelitian selanjutnya.

\section{Uji Hipotesis}

Uji parsial pada penelitian ini diuji dengan melihat angka pada angka sig pada tabel dengan hasil uji ditampilkan pada tabel berikut:

\section{Tabel 7. Uji Parsial}

\begin{tabular}{|c|c|c|c|c|c|c|}
\hline \multirow[b]{3}{*}{ Model } & \multicolumn{5}{|c|}{ Coefficients $^{a}$} & \multirow[b]{3}{*}{ Sig. } \\
\hline & & \multicolumn{2}{|c|}{ Unstandardized Coefficients } & Standardized & & \\
\hline & & $\mathrm{B}$ & Std. Error & Beta & $\mathrm{t}$ & \\
\hline 1 & (Constant) & -1.758 & 1.809 & & -.972 & .333 \\
\hline & Dapat_Dipercaya_Total & .181 & .153 & .052 & 1.188 & .237 \\
\hline & Keahlian_Total & .319 & 209 & .091 & 1.525 & .130 \\
\hline & Daya_Tarik_Fisik_Total & .298 & .222 & .083 & 1.343 & .182 \\
\hline & Kualitas_Dihargai_Total & 1.933 & .177 & .503 & 10.915 & .000 \\
\hline & Kesamaan_Total & 1.355 & .155 & .351 & 8.763 & .000 \\
\hline & Popularitas_Total & .368 & .204 & .082 & 1.803 & .074 \\
\hline & Kekuatan_Persuasif_Total & .502 & .212 & .110 & 2.374 & .019 \\
\hline
\end{tabular}

a. Dependent Variable: CM_Total

Sumber: SPSS 25.0; $n=136$ 
Variabel Dapat Dipercaya (X1) mempunyai nilai $\mathrm{t}$ hitung sebesar 1,188 dengan probabilitas sebesar 0,237 , karena probabilitas lebih dari 0,05 dan $\mathrm{t}$ hitung $<\mathrm{t}$ tabel $(1,188<1,977)$ maka variabel Dapat Dipercaya (X1) secara parsial tidak berpengaruh signifikan terhadap variabel Citra merek (Y) sehingga hipotesis pertama (H1) dalam penelitian ini ditolak. Oleh karena itu dapat dijelaskan bahwa Citra Merek pada Smartphone VIVO tidak dipengaruhi oleh faktor sosok Agnes Monica sebagai celebrity endorser yang dapat dipercaya membintangi iklan smartphone VIVO. Hasil ini tidak mendukung hasil penelitian yang dilakukan oleh Cholifah, Suharyono, \& Hidayat (2016). Penelitian ini menggunakan produk alat kosmetik Wardah dengan jumlah sampel responden sebanyak 108 orang di Malang, Indonesia. Hasil ini juga menolak hasil penelitian (Marselina \& Siregar, 2017) yang meneliti mengenai faktor "dapat dipercaya" pada citra merek produk kosmetik Wardah di Bogor, Indonesia dengan melibatkan 30 orang responden. Berdasarkan hasil ini penggunaan sosok Agnes Monica sebagai celebrity endorser sebaiknya tidak digunakan untuk membentuk citra merek smartphone VIVO namun bisa digunakan untuk lebih ke arah perkenalan (launching) untuk mendukung angka penjualan saja bukan pada pembentuk citra merek smartphone VIVO itu sendiri.

Variabel Keahlian (X2) mempunyai nilai $\mathrm{t}$ hitung sebesar 1,525 dengan probabilitas sebesar 0,130, karena probabilitas lebih dari 0,05 dan $\mathrm{t}$ hitung $<\mathrm{t}$ tabel $(1,525<1,977)$ maka variabel Keahllian (X2) secara parsial tidak berpengaruh signifikan terhadap variabel Citra merek (Y) sehingga hipotesis kedua (H2) dalam penelitian ini ditolak. Oleh karena itu dapat dijelaskan bahwa Citra Merek pada Smartphone VIVO tidak dipengaruhi oleh faktor keahlian Agnes Monica sebagai celebrity endorser dalam membintangi iklan smartphone VIVO. Hasil ini tidak mendukung hasil penelitian yang dilakukan oleh Marselina \& Siregar
(2017) yang meneliti mengenai faktor "dapat dipercaya" pada citra merek produk kosmetik Wardah di Bogor, Indonesia dengan melibatkan 30 orang responden. Namun demikian, hasil penelitian ini mendukung penelitian yang dilakukan oleh Cholifah, Suharyono, \& Hidayat (2016) yang meneliti produk alat kosmetik Wardah dengan jumlah sampel responden sebanyak 108 orang di Malang, Indonesia. Berdasarkan hasil ini penggunaan sosok Agnes Monica sebagai celebrity endorser yang memiliki keahlian dalam seni peran berbagai produk nyatanya tidak sesuai pada produk smartphone VIVO.

Variabel Daya Tarik Fisik (X3) mempunyai nilai $\mathrm{t}$ hitung sebesar 1,343 dengan probabilitas sebesar 0,182 , karena probabilitas lebih dari 0,05 dan t hitung $<\mathrm{t}$ tabel $(1,343<1,977)$ maka variabel Daya Tarik Fisik (X3) secara parsial tidak berpengaruh signifikan terhadap variabel Citra merek (Y) sehingga hipotesis ketiga (H3) dalam penelitian ini ditolak. Oleh karena itu dapat dijelaskan bahwa Citra Merek pada Smartphone VIVO tidak dipengaruhi oleh faktor Daya tarik Fisik sosok Agnes Monica sebagai celebrity endorser dalam membintangi iklan smartphone VIVO. Hasil ini tidak mendukung hasil penelitian yang dilakukan oleh Cholifah, Suharyono, \& Hidayat (2016). Penelitian ini menggunakan produk alat kosmetik Wardah dengan jumlah sampel responden sebanyak 108 orang di Malang, Indonesia. Hasil ini juga menolak hasil penelitian (Marselina \& Siregar, 2017) yang meneliti mengenai faktor "daya tarik fisik" pada citra merek produk kosmetik Wardah di Bogor, Indonesia dengan melibatkan 30 orang responden. Berdasarkan hasil ini dapat dijelaskan bahwa daya tarik fisik sosok Agnes Monica sebagai celebrity endorser tidak digunakan untuk citra merek smartphone VIVO. Daya tarik fisik sosok Agnes Monica sebagai celebrity endorser diindikasikan dapat digunakan untuk pengaruh kesuksesan memasarkan produk smartphone VIVO.

Variabel Kualitas Dihargai (X4) mempunyai nilai $\mathrm{t}$ hitung sebesar 10,915 
dengan probabilitas sebesar 0,00 , karena probabilitas kurang dari 0,05 dan $t$ hitung > $\mathrm{t}$ tabel $(10,915>1,977)$ maka variabel Kualitas Diri (X4) secara parsial berpengaruh signifikan terhadap variabel Citra merek (Y) sehingga hipotesis keempat (H4) dalam penelitian ini diterima. Oleh karena itu dapat dijelaskan bahwa Citra Merek pada Smartphone VIVO dipengaruhi oleh faktor Kualitas Diri sosok Agnes Monica sebagai celebrity endorser dalam membintangi iklan smartphone VIVO. Hasil ini mendukung hasil penelitian yang dilakukan oleh Cholifah, Suharyono, \& Hidayat (2016). Penelitian ini menggunakan produk alat kosmetik Wardah dengan jumlah sampel responden sebanyak 108 orang di Malang, Indonesia. Hasil ini juga mendukung hasil penelitian Marselina \& Siregar (2017) yang meneliti mengenai faktor "kualitas dihargai" pada citra merek produk kosmetik Wardah di Bogor, Indonesia dengan melibatkan 30 orang responden. Berdasarkan hasil ini dapat dijelaskan bahwa kualitas diri fisik sosok Agnes Monica dihargai dan tidak diragukan dalam prestasinya sebagai celebrity endorser. Hal inilah yang digunakan dan dimanfaatkan oleh VIVO sebagai pemain baru di industri smartphone.

$$
\text { Variabel Kesamaan }
$$

mempunyai nilai t hitung sebesar 8,763 dengan probabilitas sebesar 0,00 , karena probabilitas kurang dari 0,05 dan thitung > $\mathrm{t}$ tabel $(8,763>1,977)$ maka variabel Kesamaan (X5) secara parsial berpengaruh signifikan terhadap variabel Citra merek (Y) sehingga hipotesis kelima (H4) dalam penelitian ini diterima. Oleh karena itu dapat dijelaskan bahwa Citra Merek pada Smartphone VIVO dipengaruhi oleh faktor Kesamaan sosok Agnes Monica sebagai celebrity endorser dalam membintangi iklan smartphone VIVO. Hasil ini mendukung hasil penelitian yang dilakukan oleh Cholifah, Suharyono, \& Hidayat (2016). Penelitian ini menggunakan produk alat kosmetik Wardah dengan jumlah sampel responden sebanyak 108 orang di Malang, Indonesia. Hasil ini juga mendukung hasil penelitian Marselina \&
Siregar (2017) yang meneliti mengenai faktor "kesamaan" pada citra merek produk kosmetik Wardah di Bogor, Indonesia dengan melibatkan 30 orang responden. Berdasarkan hasil ini dapat dijelaskan bahwa pemilihan dan penggunan sosok Agnes Monica sudah sesuai sebagai celebrity endorser smartphone VIVO.

$$
\text { Variabel Popularitas }
$$

mempunyai nilai $\mathrm{t}$ hitung sebesar 1,803 dengan probabilitas sebesar 0,074, karena probabilitas lebih dari 0,05 dan $\mathrm{t}$ hitung $<\mathrm{t}$ tabel $(1,803<1,977)$ maka variabel Popularitas (X6) secara parsial tidak berpengaruh signifikan terhadap variabel Citra merek (Y) sehingga hipotesis keenam (H6) dalam penelitian ini diterima. Oleh karena itu dapat dijelaskan bahwa Citra Merek pada Smartphone VIVO dipengaruhi oleh faktor Popularitas sosok Agnes Monica sebagai celebrity endorser dalam membintangi iklan smartphone VIVO. Hasil ini menolak hasil penelitian yang dilakukan oleh Cholifah, Suharyono, \& Hidayat (2016). Penelitian ini menggunakan produk alat kosmetik Wardah dengan jumlah sampel responden sebanyak 108 orang di Malang, Indonesia. Hasil ini juga menolak hasil penelitian Marselina \& Siregar (2017) yang meneliti mengenai faktor "popularitas" pada citra merek produk kosmetik Wardah di Bogor, Indonesia dengan melibatkan 30 orang responden. Berdasarkan hasil ini dapat dijelaskan bahwa popularitas sosok Agnes Monica sebagai celebrity endorser tidak sesuai untuk tujuan membentuk citra merek smartphone VIVO.

Variabel Kekuatan Persuasif (X7) mempunyai nilai $\mathrm{t}$ hitung sebesar 2,374 dengan probabilitas sebesar 0,019 , karena probabilitas kurang dari 0,05 dan t hitung > $\mathrm{t}$ tabel $(2,374>1,977)$ maka variabel Kekuatan Persuasif (X7) secara parsial berpengaruh signifikan terhadap variabel Citra merek (Y) sehingga hipotesis ketujuh (H7) dalam penelitian ini diterima. Oleh karena itu dapat dijelaskan bahwa Citra Merek pada Smartphone VIVO dipengaruhi oleh faktor Kekuatan Persuasif sosok Agnes Monica sebagai celebrity endorser dalam 
membintangi iklan smartphone VIVO. Hasil ini sesuai hasil penelitian yang dilakukan oleh Cholifah, Suharyono, \& Hidayat (2016). Penelitian ini menggunakan produk alat kosmetik Wardah dengan jumlah sampel responden sebanyak 108 orang di Malang, Indonesia. Hasil ini juga mendukung hasil penelitian Marselina \& Siregar (2017) yang meneliti mengenai faktor "popularitas" pada citra merek produk kosmetik Wardah di Bogor,
Indonesia dengan melibatkan 30 orang responden. Berdasarkan hasil ini dapat dijelaskan bahwa popularitas sosok Agnes Monica sebagai celebrity endorser mampu membentuk kekuatan persuasif bagi smartphone VIVO.

Uji simultan pada penelitian ini diuji dengan melihat angka pada angka sig pada tabel dengan hasil uji ditampilkan pada tabel berikut:

\section{Tabel 8. Uji Simultan}

\begin{tabular}{|c|c|c|c|c|c|c|}
\hline & & & $\mathrm{OVA}^{\mathrm{a}}$ & & & \\
\hline & & $\begin{array}{l}\text { Sum of } \\
\text { Squares }\end{array}$ & df & Mean Square & $\mathrm{F}$ & Sig. \\
\hline 1 & Regression & 4204.350 & 7 & 600.621 & 96.876 & $.000^{\mathrm{b}}$ \\
\hline & Residual & 793.584 & 128 & 6.200 & & \\
\hline & Total & 4997.934 & 135 & & & \\
\hline
\end{tabular}

a. Dependent Variable: CM_Total

b. Predictors: (Constant), Kekuatan_Persuasif_Total, Kualitas_Diri_Total,

Kesamaan_Total, Dapat_Dipercaya_Total, Popularitas_Total, Keahlian_Total,

Daya_Tarik_Fisik_Total

Sumber: SPSS 25.0; $\mathrm{n}=136$

Berdasarkan tabel di atas dapat dijelaskan bahwa angka yang diperoleh pada baris sig berada pada angka 0,000 atau di bawah 0,05. Hal ini menyatakan bahwa Citra Merek dipengaruhi secara simultan oleh faktor-faktor Dapat Dipercaya, Keahlian, Daya Tarik Fisik, Kualitas Dihargai, Kesamaan, Popularitas, dan Kekuatan Persuasif. Hasil ini menjelaskan menerika Hipotesis kedelapan. Hasil ini mengindikasikan bahwa pemilihan dan penggunaan sosok Agnes Monica sebagai celebrity endorser dalam membentuk citra merek smartphone VIVO dinilai dpengaruhi secara bersamaan oleh faktor- faktor Dapat Dipercaya, Keahlian, Daya Tarik Fisik, Kualitas Dihargai, Kesamaan, Popularitas, dan Kekuatan Persuasif. Hasil ini secara keseluruhan sesuai dengan penelitian yang dilakukan oleh Cholifah, Suharyono, \& Hidayat (2016) dan tidak sepenuhnya mendukung penelitian yang dilakukan oleh Marselina \& Siregar (2017).

\section{Persamaan Regresi}

Untuk mengetahui pengaruh beberapa variabel bebas terhadap variabel terikat dilakukan analisis regresi linier berganda dari tabel di bawah ini. 


\section{Tabel 9. Persamaan Regresi}

\begin{tabular}{|c|c|c|c|}
\hline \multirow[b]{2}{*}{ Model } & & \multicolumn{2}{|c|}{ Unstandardized Coefficients } \\
\hline & & B & Std. Error \\
\hline \multirow[t]{8}{*}{1} & (Constant) & -1.758 & 1.809 \\
\hline & Dapat_Dipercaya_Total & .181 & .153 \\
\hline & Keahlian_Total & .319 & .209 \\
\hline & Daya_Tarik_Fisik_Total & .298 & .222 \\
\hline & Kualitas_Dihargai_Total & 1.933 & .177 \\
\hline & Kesamaan_Total & 1.355 & .155 \\
\hline & Popularitas_Total & .368 & .204 \\
\hline & Kekuatan_Persuasif_Total & .502 & .212 \\
\hline
\end{tabular}

Sumber: diolah penulis dengan SPSS 25.0; $\mathrm{n}=136$

Berdasarkan hasil analisis diperoleh model regresi linear berganda:

$$
Y=-1,758+0,181 X 1+0,319 X 2+0,298 X 3+1,933 X 4+1,355 X 5+0,368 X 6+0,502 X 7
$$

Persamaan ini dapat dijelaskan sebagai berikut:

1. Konstanta sebesar $-1,758$ adalah nilai citra merek apabila variabel dapat dipercaya, keahlian, daya tarik fisik, kualitas dihargai, kesamaan, popularitas, kekuatan persuasif bernilai 0 (nol).

2. Koefisien regresi variabel dapat dipercaya sebesar 0,181 berarti jika dapat dipercaya meningkat sebesar satu satuan maka citra merek akan meningkat sebesar 0,181 satuan dengan asumsi lain dianggap tetap.

3. Koefisien regresi variabel keahlian sebesar 0,319 berarti jika keahlian meningkat sebesar satu satuan maka citra merek akan meningkat sebesar 0,319 satuan dengan asumsi lain dianggap tetap.

4. Koefisien regresi variabel daya tarik fisik sebesar 0,298 berarti jika daya tarik fisik meningkat sebesar satu satuan maka citra merek akan meningkat sebesar $\mathbf{0 , 2 9 8}$ satuan dengan asumsi lain dianggap tetap.

5. Koefisien regresi variabel kualitas dihargai sebesar $\mathbf{1 , 9 3 3}$ berarti jika kualitas dihargai meningkat sebesar satu satuan maka citra merek akan meningkat sebesar 1,933 satuan dengan asumsi lain dianggap tetap.
6. Koefisien regresi variabel kesamaan sebesar 1,355 berarti jika kesamaan meningkat sebesar satu satuan maka citra merek akan meningkat sebesar $\mathbf{1 , 3 5 5}$ satuan dengan asumsi lain dianggap tetap.

7. Koefisien regresi variabel popularitas sebesar 0,368 berarti jika popularitas meningkat sebesar satu satuan maka citra merek akan meningkat sebesar 0,368 satuan dengan asumsi lain dianggap tetap.

8. Koefisien regresi variabel kekuatan persuasif sebesar $\mathbf{0 , 5 0 2}$ berarti jika kekuatan persuasif meningkat sebesar satu satuan maka citra merek akan meningkat sebesar $\mathbf{0 , 5 0 2}$ satuan dengan asumsi lain dianggap tetap.

\section{SIMPULAN DAN SARAN}

\section{Simpulan}

Berdasarkan hasil penelitian yang sudah dijelaskan di atas maka simpulan penelitian ini adalah sebagai berikut:

1. Variabel Dapat Dipercaya (X1) secara parsial tidak berpengaruh signifikan terhadap variabel Citra merek (Y) sehingga hipotesis pertama (H1) dalam penelitian ini ditolak.

2. Variabel Keahlian (X2) secara parsial tidak berpengaruh signifikan terhadap 
variabel Citra merek (Y) sehingga hipotesis kedua $(\mathrm{H} 2)$ dalam penelitian ini ditolak.

3. Variabel Daya Tarik Fisik (X3) secara parsial tidak berpengaruh signifikan terhadap variabel Citra merek (Y) sehingga hipotesis ketiga (H3) dalam penelitian ini ditolak.

4. Variabel Kualitas Diri (X4) secara parsial berpengaruh signifikan terhadap variabel Citra merek (Y) sehingga hipotesis keempat (H4) dalam penelitian ini diterima.

5. Variabel Kesamaan (X5) secara parsial berpengaruh signifikan terhadap variabel Citra merek (Y) sehingga hipotesis kelima (H4) dalam penelitian ini diterima.

6. Variabel Popularitas (X6) secara parsial tidak berpengaruh signifikan terhadap variabel Citra merek (Y) sehingga hipotesis keenam (H6) dalam penelitian ini diterima.

7. Variabel Kekuatan Persuasif (X7) secara parsial berpengaruh signifikan terhadap variabel Citra merek (Y) sehingga hipotesis ketujuh (H7) dalam penelitian ini diterima.

8. Citra Merek dipengaruhi secara simultan oleh faktor-faktor Dapat Dipercaya, Keahlian, Daya Tarik Fisik, Kualitas Dihargai, Kesamaan, Popularitas, dan Kekuatan Persuasif.

9. Persamaan regresi yang terbentuk adalah: $\mathrm{Y}=-1,758+0,181 \mathrm{X} 1+$ $0,319 \mathrm{X} 2+0,298 \mathrm{X} 3+1,933 \mathrm{X} 4+$ $1,355 \times 5+0,368 \times 6+0,502 \times 7$

\section{Saran}

Berdasarkan simpulan di atas, saran yang ditekankan pada penelitian ini adalah pada faktor-faktor spesisifk berikut:

1. Pada faktor "Dapat Dipercaya" dalam kaitannya dengan citra merek sebaiknya perusahaam smartphone VIVO lebih memilih celebrity endorser yang secara konsisten aktif membintangi produkproduk smartphone. Pemilihan celebrity endorser juga perlu memperhatikan faktor jam terbang celebrity endorser tersebut dalam melakukan ulasan (review) smartphone. Upaya ini diindikasikan dalam membentuk faktor kepercayaan bagi pengguna atau calon pengguna dan sekaligus mendukung pembentukan citra merek smartphone VIVO.

2. Dalam meningkatkan faktor keahlian, disarankan perusahaan smartphone VIVO memberikan masa coba menggunakan smartphone dengan merek yang sama kepada celebrity endorser yang akan dikontrak. Masa coba itu akan memberikan efektivitas dalam mengenal smartphone yang akan dibintangi dan dapat membentuk persepsi pengguna/calon pengguna yang nantinya melihat iklan yang dibintangi oleh celebrity endorser tersebut.

3. Produk smartphone berbeda dengan produk sajian makanan ataupun minuman yang dapat dengan mudah berkaitan dengan citra merek. Citra merek perusahaan smartphone seperti VIVO dinilai mampu dibentuk dari celebrity endorser yang dipandang melek teknologi khususnya smartphone, sehingga secara sosok, (calon) pengguna dapat menilai kesesuian sosok fisik yang menjadi daya tarik dalam membintangi produk smartphone untuk membentuk citra merek perusahaan tersebut.

4. Faktor popularitas tidak berlaku mutlak dalam memengaruhi citra merek produk smartphone VIVO. Popularitas dinilai dapat digunakan untuk mendukung upaya pemasaran. Oleh karena itu, sebaiknya celebrity endorser sebaiknya digunakan beberapa orang sesuai dengan misi dan tujuan perusahaan. Misalnya pada saat launching produk, sosok Agnes Monica digunakan untuk mendukung keberhasilan launching produk dan mendukung upaya pemasaran. Untuk membentuk citra merek dapat menggunakan celebrity endorser yang lain yang lebih dapat menggunakan populatitasnya untuk tujuan membentuk citra merek. 


\section{DAFTAR PUSTAKA}

Bachdar, S. 2017. Kekuatan Influencer Marketing di Balik Layar Vivo. Diakses pada tanggal 6 April 2018, from www.marketeers.com: http://marketeers.com/kekuataninfluencer-marketing-di-baliklayar-vivo/

Cholifah, N., Suharyono, \& Hidayat, K. 2016. Pengaruh Celebrity endorser Terhadap Brand Image (Survei pada Konsumen Kosmetik Wardah di Counter Wardah Kota Malang). Jurnal Administrasi Bisnis (JAB), 36(1), 170-177.

Ismayanti, N. A., \& Santika, I. 2017. Pengaruh Celebrity endorser, Brand Image, Kualitas Produk Terhadap Niat Beli Sepatu Olahraga Nike Di Kota Denpasar. E-Jurnal Manajemen Unud, 610, 5720-5747.

Kotler, P., \& Keller, K. L. 2012. Marketing Management 14 ed.. United States of America: Pearson Education.

Kotler, P., \& Kevin, K. L. 2009. Manajemen Pemasaran 13 ed., Vol. 1. Jakarta: Erlangga.

Marselina, D., \& Siregar, E. H. 2017. Pengaruh Celebrity endorser terhadap Brand Image pada Kosmetik Wardah di Bogor. Jurnal Manajemen dan Organisasi, VIIII, 15-27.

Moriarty, S., Mitchell, N., \& Wells, W. 2011. Advertising. Jakarta: Kencana Prenada Media Group.

Rini, E. S., \& Astuti, D. W. 2012. Pengaruh Agnes Monica Sebagai Celebrity endorser Terhadap Pembentukan Brand Image Honda Vario. Bisma Jurnal Bisnis dan Manajemen, 61, $1-12$.

Rodiyaan, G., \& Madiawati, P. N. 2016. Pengaruh Celebrity endorser Agnes Monica Terhadap Brand Image Pada Sampo Clear Women. $e$ Proceeding of Management, $\mathrm{p}$. 3492.
Rossiter, J., \& Smidts, A. 2012. print advertising: Celebrity presenters. Journal of Business Research, 659, 874.

Saparso, \& Lesatari, D. 2009. Peranan Endorser Terhadap Brand Image Dari Sudut Pandang Konsumen. Jurnal Ilmiah Manajemen Bisnis, 93, 161-180.

Shimp, T. 2003. Periklanan Promosi: Aspek Tambahan Komunikasi Pemasaran Terpadu Vol. 1. Jakarta: Eerlangga. . 2007. Integrated Marketing Communication In Advertising And Promotion 7 ed.. USA: Thomson South-Western.

Supriyadi, C. 2014. ZTE Smartphone: Tak Semua Produk Buatan Cina Rendah Kualitas. Diakses pada tanggal 6 April 6 2018, from www.marketing.co.id: https://marketing.co.id/ztesmartphone-tak-semua-produkbuatan-cina-rendah-kualitas/

Suryadi, D. 2017. Tiga Bersaudara Berebut Pasar Ponsel Indonesia. Diakses pada tanggal 6 April 2018, from www.swa.co.id:

https://swa.co.id/swa/trends/marketi ng/tiga-bersaudara-berebut-pasarponsel-indonesia

Vendors' market share of smartphone shipments in Indonesia from 2014 to 2017*. 2018. Diakses pada tanggal 6 April 2018, from www.statista.com: https://www.statista.com/statistics/5 16302/indonesia-smartphoneshipments-vendor-market-share/ www.marketeers.com. 2017. Inilah Jawara Indonesia WOW Brand Tahun Ini. Diakses pada tanggal 6 April 6 2018, from www.marketeers.com: http://marketeers.com/inilahjawara-indonesia-wow-brandtahun-ini/ 
www.topbrand-award.com. n.d.. TOP BRAND FASE 12017 Kategori : Telekomunikasi/ It. Diakses pada tanggal April 6, 2018, from www.topbrand-award.com: http://www.topbrandaward.com/top-brandsurvey/surveyresult/top_brand_index_2017_fase_ 1 